\title{
The Discursive Construction of Teachers' Desirable Identity on a Social Networking Site
}

\author{
Radzuwan Ab Rashid (Corresponding author) \\ Faculty of Languages and Communication, Universiti Sultan Zainal Abidin, Gong Badak Campus, 21300 Kuala Nerus, Terengganu, Malaysia \\ E-mail: radzuwanrashid@unisza.edu.my \\ Kamariah Yunus \\ Faculty of Languages and Communication, Universiti Sultan Zainal Abidin, Gong Badak Campus, 21300 Kuala Nerus, Terengganu, Malaysia \\ E-mail: kamariah@unisza.edu.my \\ Azmi, N.J. \\ Faculty of Languages and Communication, Universiti Sultan Zainal Abidin, Gong Badak Campus, 21300 Kuala Nerus, Terengganu, Malaysia \\ E-mail: jijidianaazmi@unisza.edu.my \\ Safawati Basirah, Z. \\ Faculty of Languages and Communication, Universiti Sultan Zainal Abidin, Gong Badak Campus, 21300 Kuala Nerus, Terengganu, Malaysia \\ E-mail: safawatibasirah@unisza.edu.my \\ Shireena Basree Abdul Rahman \\ Faculty of Education, Universiti Teknologi MARA, Puncak Alam Campus, 42300 Bandar Puncak Alam, Selangor, Malaysia. \\ E-mail: s_basree@yahoo.com \\ Yusoff, S.Z. \\ Faculty of Languages and Communication, Universiti Sultan Zainal Abidin, Gong Badak Campus, 21300 Kuala Nerus, Terengganu, Malaysia \\ E-mail: zanariahyusoff@unisza.edu.my
}

Received: 11-04-2016

Published: 01-09-2016
Accepted: 23-06-2016

doi:10.7575/aiac.ijalel.v.5n.5p.139
Advance Access Published: July 2016

URL: http://dx.doi.org/10.7575/aiac.ijalel.v.5n.5p.139

\begin{abstract}
This study is situated in the broader identity-construction literature. Bringing discourse community theory to examine teachers' postings on Facebook Timelines, we explored how teachers discursively construct socially desirable identities to fit into the Timeline community. Data were gathered from the Status updates and Comments on 29 Timelines belonged to Malaysian English language teachers who were purposively chosen as they often posted and commented on teaching-related issues on their Timelines. The analysis shows that the commonest form of identity construction on the teachers' Timelines was as an engager which had been carefully constructed to portray positive self-image. This paper concludes that when participating on a public networking site, the teachers were being strategic as not to construct identities which could tarnish their professional image.
\end{abstract}

Keywords: English language teachers, Malaysia, discursive identity, Facebook, engager

\section{Introduction}

The birth of the internet in computer technology has been celebrated as part of the modern life. The use of internet has been phenomenal in the past two decades since the web development gained its speed and momentum in society (Faimau, 2007). The development of social networking sites during the later part of 2000s brings new opportunities for internet users to become 'producers rather than simply users of contents produced for them by social, political, and cultural institutions, and commercial companies' (Campbell, 2012, p.44). The recent proliferation in the use of social networking sites (SNSs) has resulted in new studies examining the role that SNSs play in identity construction (e.g.Schwartz and Halegoua, 2015; Rashid et al., 2016). Research on identity has been approached from many perspectives, such as the psychological perspective (e.g. Bruner, 1995; Erikson, 1959), sociolinguistic perspective (e.g. Schriffin, 1996; Rashid, Rahman, and Rahman, 2016) and educational perspective (e.g. Hammersley, 2002). This paper aims to contribute to the existing literature by providing insights into how Malaysian English language teachers construct the identity of an engager in their daily lives on Facebook Timelines. 


\section{Discursive Identity}

The aim of this section is not to provide a thoroughgoing history of the concept of identity, but to discuss in some depth the discursive view of identity as this paper closely focuses on teachers' discursive behavior on Facebook Timelines. Benwell and Stokoe (2006) and Gee (2000) conceptualize identity as 'being recognized as a certain kind of person in a given context' (p.99). Gee refers to discursive identity as 'D-identity' and he emphasizes the socio-constructionist aspect of this type of identity that it cannot be 'achieved all by oneself' ( $p .103)$. The particular trait, such as being an engaging teacher is only recognized when 'other people treat, talk about, and interact' with them (ibid, p.103).

Discursive identity construction is closely related to Goffman's (1959) 'self-presentation' (p.4). Jones and Pittman (1982) suggest individuals can present themselves in particular ways using five impression-management techniques enacted through discourse: self-promotion, ingratiation, exemplification, intimidation, and supplication. Self-promotion is used by individuals to present themselves as being capable of doing something by highlighting their selfachievements whilst ingratiation is used to convey an impression of being likeable. Exemplification is used to convey an impression of being hardworking and committed beyond what is necessary or expected in completing particular tasks. Intimidation is used to convey an impression of being powerful, while supplication is used to receive compassion and assistance from others by presenting the self as weak.

Many scholars (e.g. Davies, 1989; Haniford, 2010; Rashid, 2016a) agree that the fundamental principle underlying the theory of discursive identity construction is that individuals do not have fixed identities since identities are constituted and reconstituted by the various discursive practices in which they participate. On the other hand, Haniford argues that discursive practices are influenced by specific contexts and the position inhabited by individuals within a particular social space. Understanding discursive identities requires more than the verbal analysis of discourse, but needs to include various socio-cultural aspects of discourse - where and when the discourse occurred and who was involved - to fully understand teachers' discursive identities in a particular context. Identities constructed in the discourse involving teachers and students in the classroom are most likely to be different from the identities constructed in the discourse involving colleagues in the staffroom.

The emergence of SNS, such as Facebook and Twitter, affords teachers a platform to construct identities where they are simultaneously 'watched' by multiple audiences with various backgrounds. Borrowing Goffman's (1959) dramaturgical framework, which conceptualizes identity or the self as a dramatic effect based upon how individuals act (in the theatrical sense), the Timelines are the 'front stages' where discursive social performances take place.

Discursive identity is created through engaging in interactions with other people, thus it is fluid rather than stable as different identities are constructed in different contexts, either by individuals or ascribed to them by other people. To accomplish or be ascribed their desired identities, individuals may use different kinds of impression-management techniques and discursive psychology strategies.

\section{Discourse community}

Proponents of the concept of discourse community, such as Swales (1988, 1990), Johns (1997) and Pogner (2005), all define a discourse community as a group of communicators who share common goals or interests and adopt certain preferred discursive practices in public discussion. In his conceptualization of discourse community, Swales (1990) proposed six defining characteristics that he argues are both necessary and sufficient to identify a particular group of people as a discourse community discussed in the following paragraphs.

A discourse community has 'a broadly agreed set of common public goals' related to the interests of community members which can be formally stated or be more tacit in nature (Swales, 1990, p.471). Swales emphasizes the 'publicness' of a discourse community as a result of it having no restrictions on who can join. For instance, a discourse community on Timelines may consist of non-teaching Friends from diverse backgrounds, individuals from different professions or family members. The members of this community participate to have 'informational opportunities' and feedback from each other (p.472), which resonates with participation in Gee's (2005) affinity space as highlighted in Rashid (2016a).

In addition, a discourse community has 'mechanisms of intercommunication among its members' which often vary according to the community (Swales, 1990, p.471) and may include 'meetings, telecommunications, correspondence, newsletters, conversations and so forth' (p.472). In the case of the teachers in this study, the mechanism of intercommunication is written conversations used as a means to interact with each other through the Status update and Comment functions.

What makes a discourse community differ from Lave and Wenger's (1991) Community of Practice (CoP) and Gee's (2005) affinity space is its focus on the discourse elements of the community. For Swales (1990), a discourse community 'has and continues to develop discoursal expectations' of how members can get things done through the use of language - the 'appropriacy of topics, form, function, and positioning of discoursal elements' (p.472). It also has a specific lexis such as community-specific abbreviations and acronyms (e.g. SBA). Its members consist of individuals with different levels of 'content and discoursal expertise' (p.472). For instance, English language teachers with varying levels of grammar (content) knowledge or skills in effectively holding a conversation may form a discourse community as membership is not restricted to teachers with the same level of expertise. 


\section{Research Design}

This study closely focused on the participants' unfolding discourse as they interact on Timelines. The participants are 29 Malaysian English language teachers teaching in secondary schools across the country. These teachers were purposively chosen as they often posted and commented on teaching-related issues on their Timelines. The data set consists of 178 teaching-related Status updates on the Timelines, together with the 1226 Comments that these had attracted. Ethical and methodological issues that arose in this study have been discussed in a paper published by Nottingham Jubilee Press (see Rashid, 2014).

Discourse analysis in its broadest sense and discursive psychology are the two different forms of discursive analytical approach employed in this study. Broad discourse analysis provides a framework for understanding general communicative behaviour within which syntax, semantics and pragmatics can be situated (Miller, 2004). The foci of analysis in this broad discourse analysis approach are traditional theoretical linguistics, such as choice of syntactic construction, choice and structure of referring expression/noun phrases, choice of tense and aspect and choice of word order.

Besides broad discourse analysis, Edwards and Potter's (1992) discursive psychology is also employed as an analytical approach in this study to examine how teachers construct their desired identities through the Status updates and Comments on their Timelines. Employing discursive psychology enabled the exploration of how identities are handled and managed in discourse. The foci of analysis suggested by Edwards and Potter are those involving blame, justification and defence.

\section{Discussion and Analysis- The engager}

This section discusses three examples of Status updates where the identity of an engager is salient. These Status updates are chosen to highlight different strategies employed by teachers in constructing their identities.

Extract 1 is a Status update taken from Liza's Timeline where she constructs the identity of an engager by presenting herself as a curious teacher willing to learn from ex-students in order to become a better teacher. She introduces the topic by asking her ex-students how they improved English after leaving secondary school and what activities the students would have liked to have had when they were in secondary school.

\section{Extract 1}

1 Salam n good morning!

2 to my ex-students-some questions.

3 what activities actually helped you to improve your English?

4 in school or at university.

$5 \quad$ i know some students actually improved so much

6 when you go to matriks/foundation.

7 how did you improve?

8 and what activities did you wish you have

9 so that you could have improved your English earlier?

10 Thank you for your response! Have a great day!

\section{(Liza/SU1)}

Liza begins this Status update with a proper greeting (line 1) which is rarely done by other teachers on Timelines. The way Liza 'speaks' to her ex-students in this online space resembles the common pattern of a teacher who talks to their students face-to-face in the classroom. This implies that Liza maintains her institutional identity as a teacher, even when interacting with students on Facebook. She begins with a proper greeting just like what a teacher always does when they are about to begin a class. This Status update is also written using 'non-vernacular language' or a 'specialist style of language' (Gee, 2014, p.8) which contributes to the projection of her institutional identity.

Liza's curiosity is made explicit by asking three questions in a single Status update. Tsui (1992) identifies three functions of questions: to elicit information, to elicit confirmation of the speaker's assumption, and to elicit agreement about what has been said by the speaker. All the questions asked in this Status update function to elicit information, thus emphasizing her eagerness to learn. The first question is about the activities that helped them improve their English (line 3). She then adds, in school or at university (line 4).

Despite being a school teacher, Liza is also interested to know about effective language-enhancement activities carried out both in school and at university, hence emphasizing her identity as a curious teacher. She uses an empirical construction (Potter, 1996) when she says she knows some students improved a lot when they did matriculation/foundation courses (lines 5-6). By doing this, she creates an empirical basis for her curiosity.

Liza then moves from the what to the how question when she asks them how they improved (line 7). She moves on from the easy question asking students to describe what activities to the more difficult question of how, which requires explaining the process of improving their language skills. Her curiosity and eagerness does not affect her effective questioning strategy, which is to start from the low order thinking questions before asking higher order thinking questions (Chuska, 1995). Liza shows acute awareness of how to get the ex-students to respond to her on Facebook so 
she can satisfy her curiosity. If she began with a higher-order question, her ex-students might just ignore the Status update. As pointed by Rashid (2016b), teachers strategically craft their Status updates so that other users will take up the topic initiated by them.

The third question Liza asks is about the activities they wish they had been involved in to improve their English earlier (lines 8-9). Her curiosity is clear in this question, showing her interest in the kind of activities that the students wish had been carried out. This question is tailored to meet the context of English language learning at school through using the word earlier, which implies she is referring to the schooling phase prior to enrolment in tertiary education. Despite showing curiosity about students' language activities at university, Liza knows her real need is knowledge of effective language activities at school. In fact, the question about language activities carried out at university could be seen as a strategy to attract more responses from her students, as it is relevant to them now they are studying at university. From another perspective, it is also reasonable to suggest that Liza is looking for teaching strategies at the university so that she could adapt and adopt the strategies in her class.

Towards the end of the Status update, Liza thanks her ex-students in advance of their responses and wishes them a great day (line 10). It is interesting that, reflecting her curiosity to learn and expand her knowledge by seeking instrumental support on Timeline, Liza does not forget her professional identity. She greets the students, formulates her questions clearly, and uses the appropriate questioning techniques as well as thanking them in advance to show appreciation of the students' (hoped for) responses. Contacting ex-students on Timelines to find out about 'pedagogical content knowledge' (Shulman, 1987, p.8) can be associated with 'self-promotion' and 'ingratiation' (Jones and Pittman, 1982). She promotes herself by showing that she is as a teacher who is willing to learn and she conveys the message that she has a close rapport with her ex-students, thus being a likeable teacher.

Besides showing curiosity to learn more, the teachers also construct the identity of an engager by showing the determination to further improve themselves as teachers. For instance, in the Status update in Extract 2, Syiba puts forth her belief that a teacher must be determined to teach students until they get a true understanding of the subject matter.

Extract 2

1 one of my students commented.

2 -ticer terlalu zuhud apbl ticer kata ticer failed bila students failed to understand apa yg ticer ajar.

(English: Teacher is too devoted when teacher said teacher failed when students failed to understand what teacher taught)

3 i said-no.cz it's a ticer's responsibility to teach something sampai students diafaham (English: until the student understands)

4 ignorance is bliss is sooooo wrong when it comes to students.

5 i must not give up. must find a way.perlu jd guru yg lebih baik!

(English: Must be a better teacher!)

(Syiba/SU5)

This Status update has the elements of storytelling in that it involves the use of a constructed dialogue (lines 2-3) and the complication when Syiba disagrees with the student (line 3). Syiba introduces the topic by highlighting how one of her students ascribed the identity of a too devoted teacher to her, which she rejects before expressing her determination to be a better teacher. Note that the subject of the opening sentence is one of her students (line 1), which makes the student the center of attention. By highlighting the fact that the student allocated this particular identity to her, Syiba avoids the risk of being seen as a bragger. To further emphasize the student's agency, she engages in 'intertextuality' (Gee, 2014, p.46) by constructing the student's dialogue (line 2). Hence readers are made to feel that they are listening to the student's original voice and not a reported statement that might have been manipulated by her. In this constructed dialogue (Tannen, 1989), Syiba uses a mixture of Malay and English, besides using the short forms such as ticer for teacher and apbl for apabila (English: when). Here Syiba employs the discursive psychology strategy of producing factual description (Edwards, 2005) to show the realness of her conversation with the students, hence convincing the readers that she is merely sharing the student's comment and not manipulating or bragging about anything.

In line 3, Syiba chooses to highlight her refusal to accept the ascribed identity, which suggests she took no pride in being described as too-devoted or too committed by her students. As pointed out by Benwell and Stokoe (2006), an ascribed identity can be resisted if individuals do not like the identity. However, in this case, Syiba resists this ascribed identity not because she does not like it but to show that she is not flattered by the student's comment, and hence should not be perceived as bragging about this quality on Facebook. Refusing the identity ascribed by the students enables Syiba to construct another identity, which is more positive than the identity of being too-devoted or too-committed by putting forward her beliefs that a teacher has responsibility for teaching something until it is understood by the student (line 3). Syiba wants to be seen as a responsible teacher who would thoroughly teach the subject matter until the students really understand, not just ask them to memorize things without any proper understanding. Similar to Liza (Extract 1), Syiba engages in 'self-promotion' and 'ingratiation' (Jones and Pittman, 1982) as she tells readers that she is perceived to be too devoted and the conversation with the student suggests that the student likes her. 
To further emphasize her determination, Syiba writes ignorance is bliss is sooooo wrong when it comes to students (line 4) which suggests she does not simply ignore students who do not understand. She spells the intensifier so with four extra 'o's to emphasize her disagreement with the phrase ignorance is bliss in this context. In her last line, the identity of a determined teacher is emphasized by highlighting her intention to improve her teaching strategies and herself as a teacher. This great determination is reflected in the use of the 'three-part list' (Potter, 1996, p.196) in I must not give up, must find a way, must be a better teacher! (line 5). The use of the exclamation mark gives an energized tone to this last line and reflects Syiba's motivation to be a good teacher.

Extract 3 is another example of a Status update used to construct the identity of an engager. This Status update is taken from Sharifah's Timeline where she constructs the identity of an engager by recounting on successful classroom activities, which show that she can perform at her very best as a teacher. Sharifah introduces the topic by sharing a successful activity carried out with her students and she thanks the students for making her professional life beautiful.

Extract 3

1 Poem in motion.

2 today $\mathrm{i}$ had fun wf my $\mathrm{f} 3 \mathrm{n} \mathrm{f} 5$ dramatizing our poem!

3 budak $x$ ngantuk, cikgu pun enjoy gelak tengok performance

mereka yg hebat2 ni...

(English: students x sleepy, and teacher enjoyed laughing

watching performance from these talented people..)

$4 \quad$ Tq kids for making my life beautiful!

\section{(Syiba/SU5)}

Sharifah makes the activity that she carried out the center of attention or the topic of this Status update, where she writes at the very beginning Poem in motion (line 1). She highlights the fun she had with her students doing this activity (line 2), which reflects the success of the activity. At the same time, she mentions that the form three and form five students also enjoyed the activity (line 2), hence emphasizing her success in catering for the needs of different levels of students.

To further emphasize the success of the activity, Sharifah reveals that the students were not sleepy and that they managed to put their talents into practice (line 3). She positions her students as being engaging to illustrate the identity of a successful teacher. She ends this Status update by thanking her students, for making her life beautiful (line 4). The exclamation mark in this last sentence shows her excitement about the successful classroom activity. This last line, which has a happy tone, is important as it creates the effect that this Status has been updated by Sharifah to share her amusement and thank her students, rather than bragging about the successful teaching strategy she used (which is not explained). By sharing the success of this classroom activity on her Timeline, Sharifah can be said to use 'selfpromotion' technique (Jones and Pittman, 1982, p.241) to manage the impression that she is capable of making student learning interesting.

\section{Conclusion}

The teachers have constructed the identity of an engager mainly by showing that they are eager to learn, by inquiring about teaching-related knowledge and information on their Timelines or expressing their determination to further improve themselves as teachers. The teachers also share their teaching-related achievements, such as carrying out effective classroom activities and getting positive feedback from students in their attempts to construct the identity of an engager. The impression management techniques used are mainly exemplification, self-promotion and ingratiation so that Friends view them as committed, capable teachers loved by their students hence portraying positive self-image of a teacher. Insights into the identity construction put forth in this paper contribute to our understanding that the teachers are being strategic when postings on the SNS that they carefully craft the postings to construct their desirable identity.

In pursuit of answers to the research question set out in this study, many new questions have emerged. Some of these questions are: Will the teachers construct a similar identity if they use other SNSs?; Is there any difference in the way teachers co-construct their common identity on Timelines and in Facebook Groups? - If yes, what are the differences? If no, why not? Further research is needed to find answers to these questions so that teachers' discursive behaviour on SNS can be further scrutinized. In other words, the teachers' discursive behaviour discussed in this paper needs to be examined in a new context. For instance, future research may focus on primary school English language teachers (rather than secondary school English language teachers), in Facebook Groups (rather than on Timelines) and possibly after a policy concerning teachers' use of SNS has been established or after Facebook has introduced new privacy settings. In addition, future studies could also take a longitudinal approach, for instance, monitoring the interactions in the coconstruction process over a two-year period. Such longitudinal research would be useful for providing insights into the development of teachers' discursive practices and whether the teachers still construct similar common identity over time. 


\section{References}

Benwell, B. and Stokoe, E. (2006). Discourse and identity. Edinburgh, UK: Edinburgh University Press.

Bruner, J. (1995). The autobiographical process. Current Sociology, 43(2), 161-177.

Campbell, H.A. (2012). Digital religion: Understanding religious practice in new media worlds. New York: Routledge.

Chuska, K. (1995). Improving classroom questions. Bloomington, IN: Phi Delta Kappa.

Davies, B. (1989). The discursive production of the male/female dualism in school settings. Oxford Review of Education, 15(3), 229-241.

Edwards, D. (2005). Discursive psychology. In Fitch, K.L. and Sanders, R.E. (Eds.) Handbook of language and social interaction (pp. 257-273). London: Erlbaum.

Edwards, D. and Potter, J. (1992). Discursive psychology. London: Sage.

Erikson, E.H. (1959). Identity and the life cycle: selected papers. Psychological Issues, 1(1), 1-171.

Faimau, G. (2007). Click here for religion: Self-presentation of religion on the internet. Verbum SVD, 48(2), $135-147$.

Gee, J.P. (2000). Identity as an analytic lens for research in education. Review of Research in Education, 25(1),99-125.

Gee, J.P. (2005). Semiotic social spaces and affinity spaces: from the age of mythology to today's schools. In Dave, B. and Tusting, K. (Eds.) Beyond communities of practice: language, power and social context (pp.214-232) Cambridge: Cambridge University Press.

Gee, J.P. (2014). An introduction to discourse analysis: theory and method. $4^{\text {th }} \mathrm{ed}$. London: Routledge.

Goffman, E. (1959). The presentation of self in everyday life. New York: Doubleday.

Hammersley, M. (2002) Educational research, policy making and practice. London: Paul Chapman.

Haniford, L.C. (2010). Tracing one teacher candidate's discursive identity work. Teaching and Teacher Education, 26(4), 987-996.

Johns, A.M. (1997). Discourse communities and communities of practice: membership, conflict, and diversity. In Johns, A.M. (Ed.) Text, role, and context: developing academic literacies (pp.51-70). New York: Cambridge University Press.

Jones, E. and Pittman, T. (1982). Toward a general theory of strategic self-presentation. In Suls, J. (Ed.) Psychological perspectives of the self (pp.231-26). Hillsdale, NJ: Erlbaum.

Lave, J. and Wenger, E. (1991) Situated learning: legitimate peripheral participation. Cambridge: Cambridge University Press.

Miller, J. (2004). Discourse analysis. Centre for Languages, Linguistic and Area Studies, University of Southampton. Retrieved from https://www.llas.ac.uk/resources/gpg/132 .

Pogner, K.H. (2005). Discourse communities and communities of practice: on the social context of text and knowledge production in the workplace. 21 st EGOS Colloquium. Retrieved from http://openarchive.cbs.dk/bitstream/handle/10398/7320/discourse $\% 20$ communities.pdf?sequence=1

Potter, J. (1996). Representing reality: discourse, rhetoric and social construction. London: Sage.

Rashid, R.A. (2014). Exploring methodological and ethical issues in researching teachers' informal learning on a social networking site : a research paper. Nottingham: Nottingham Jubilee Press.

Rashid, R.A. (2016a). Responding to 'nurturing global collaboration and networked learning in higher education'. Research in Learning Technology, 24: 31485.

Rashid, R.A. (2016b). Topic continuation strategies employed by teachers in managing supportive conversations on Facebook Timeline. Discourse Studies, 18(2), 188-203.

Rashid, R.A., Rahman, M.F.A., and Rahman, S.B.A. (2016). Teachers' engagement in social support process on a networking site. Journal of Nusantara Studies, 1(1).

Rashid, R.A., Wahab, Z., Yunus, K., Ismail, N.S., Yusof, N., Syed Omar, SNM., and Latiff Azmi, M.N. (2016). English language teachers as a dissenter on a social networking site. International Journal of Applied Linguistic and English Literature, 5(4), 72-78.

Schriffin, D. (1996). Narrative as a self-portrait: sociolinguistic constructions of identity. Cambridge: Cambridge University Press.

Schwartz, R. and Halegoua, G.R. (2015). The spatial self: Location-based identity performance on social media. New Media and Society, 17(10), 1643-1660.

Shulman, L.S. (1987). Knowledge and teaching: foundations of the new reform. Harvard Educational Review,57(1), 122.

Swales, J. (1988). Discourse communities, genres and English as an international language. World Englishes, 7(2), 211220.

Swales, J. (1990). The concept of discourse community. In: Chapelle, C., and Hunston, S. (Eds.) Genre analysis: English in academic and research settings, pp.21-32. Boston: Cambridge University Press.

Tannen, D. (1989). Talking voices. Cambridge: Cambridge University Press.

Tsui, A. (1992). A functional description of questions. In: Coulthard, M. (Ed.) Advances in spoken discourse analysis, pp.89-110. London: Routledge. 